\title{
Extended temperature optimum of photosynthetic reaction centers in Rhodobacterales
}

\author{
D. KAFTAN ${ }^{* * * *}$, H. MEDOVÁ*, V. SELYANIN ${ }^{*}, K^{*}$ KOPEJTKA ${ }^{*, * *}$, and M. KOBLÍŽEK ${ }^{*, * *,+}$ \\ Centre Algatech, Institute of Microbiology CAS, CZ-37981 Třeboň, Czech Republic ${ }^{*}$ \\ Faculty of Science, University of South Bohemia in České Budějovice, CZ-37005, Czech Republic**
}

\begin{abstract}
Temperature is one of the most important physical factors affecting microbial and biochemical processes. We investigated the performance of photosynthetic apparatus of marine photoheterotrophic bacterium Dinoroseobacter shibae under various temperatures. The primary photochemistry and electron transport was measured using variable infra-red fluorometry in the cells grown between $8-35^{\circ} \mathrm{C}$. It was found that the photosynthetic electron transport had a broad temperature optimum between $25-50^{\circ} \mathrm{C}$. Moreover, the primary charge separation stayed functional even after rising temperature up to $55^{\circ} \mathrm{C}$. The same phenomenon was observed also in other phototrophic Rhodobacterales. The psychrotolerant bacterium Roseisalinus antarcticus reached its maximum electron transport rate at $48^{\circ} \mathrm{C}, 30^{\circ} \mathrm{C}$ above its growth temperature. We propose that the extended temperature stability may be crucial to maintain photosynthetic function under situation when photosynthetic membranes heat up above their ambient temperature due to the heat dissipation of the excess light energy.
\end{abstract}

Additional key words: aerobic anoxygenic phototrophs; Rhodobaca barguzinensis; Roseobacter; variable fluorescence.

\section{Introduction}

Bacterial order Rhodobacterales (Alphaproteobacteria) embraces a large group of species differing significantly in their metabolic properties and ecology. A characteristic feature of Rhodobacterales is the presence of many species performing anoxygenic photosynthesis (Koblížek et al. 2013). These species harvest light using type- 2 reaction centers (RCs) containing bacteriochlorophyll (BChl) $a$ (Selyanin et al. 2016). Phototrophic Rhodobacterales are found in many environments including fresh water bodies, soda lakes, marine waters, sediments, and soils. These organisms frequently display a large flexibility in their oxygen or salinity tolerance. Members of the Rhodobacter (Rba.) and Rhodovulum genera represent classical examples of purple nonsulfur bacteria which synthesize pigments and perform photosynthesis under anaerobic or semiaerobic conditions. On the other hand, there exist many marine species belonging to the so called Roseobacter group, which grow and express their photosynthetic complexes in the presence of oxygen (Brinkhoff et al. 2008). These aerobic anoxygenic phototrophic (AAP) bacteria are typical photoheterotrophs, they do not fix inorganic carbon and use light energy as a supplement for their mostly heterotrophic metabolism.

It has been reported that AAP abundance positively correlated with chlorophyll concentration, bacterial abundance, and light availability (Koblížek 2015). The seasonal studies conducted in temperate coastal waters of the Baltic Sea (Mašín et al. 2006), and the western Mediterranean (Ferrera et al. 2014) also documented a positive correlation of AAP abundance and temperature. However, the observed correlations were weak, so the effect may have reflected more complex seasonal trends rather than the temperature alone.

Despite all of their physiological flexibility, phototrophic Rhodobacterales only flourish within a relatively narrow range of temperatures. The majority of cultured Rhodobacterales are mesophilic species with growth optima between $25-35^{\circ} \mathrm{C}$. Several species, Roseovarius tolerans, Staleya guttiformis, and Roseisalinus (Ris.) antarcticus, were isolated from the saline Lake Ekho in East Antarctica, but none of them are true psychrophiles (Labrenz et al. 1999, 2000, 2005). A similar situation has been documented for the opposite temperature extreme. Despite numerous attempts, no truly thermophilic species

$\overline{\text { Received }} 31$ July 2018, accepted 14 November 2018.

${ }^{+}$Corresponding author; phone: +420-384340432, e-mail: koblizek@alga.cz

Abbreviations: AAP - aerobic anoxygenic phototrophs; $\mathrm{BChl}$ - bacteriochlorophyll; $\mathrm{F}_{0}$ - minimal BChl fluorescence; $\mathrm{F}_{\mathrm{M}}-$ maximal $\mathrm{BChl}$ fluorescence; $\mathrm{F}_{\mathrm{V}}$ - variable BChl fluorescence; $\mathrm{F}_{\mathrm{V}} / \mathrm{F}_{\mathrm{M}}$ - maximal photochemical yield of RC; HPLC - high performance liquid chromatography; $\mathrm{OD}_{600}$ - optical density, turbidity measured at $600 \mathrm{~nm} ; \mathrm{RC}$ - photosynthetic reaction center.

Acknowledgements: This research was supported by GAČR project 15-00703S, the Czech Ministry of Education project Algatech Plus (LO1416), and by European Regional Development Fund Project 'Mechanisms and dynamics of macromolecular complexes: from single molecules to cells' (no. CZ.02.1.01/0.0/0.0/15_003/0000441). The authors thank Dr. Mathias Labrenz for providing his strain Roseisalinus antarcticus, Martina Hanusová for laboratory assistance, and Jason Dean for the language correction. The authors declare no competing financial interests. 
(growing above $50^{\circ} \mathrm{C}$ ) have been cultured to date (Madigan and Jung 2009, Kalashnikov et al. 2014). Most of the research on thermostability of bacterial reaction centers has been conducted with mildly thermophilic species Thermochromatium tepidum (Nozawa and Madigan 1991, Kimura et al. 2009). However, this purple sulfur bacterium (class Gammaproteobacteria) differs dramatically from Rhodobacterales regarding its ecology, physiology as well as phylogeny.

In general, temperature has a profound effect on microbial growth and activity since it directly affects the rate of biochemical reactions. Temperature may also affect the metabolic patterns, the nutritional requirements, and the composition of microbial cells. Low temperatures are known to limit respiration and restrict bacterial growth. On the other hand, a high temperature may disrupt cellular metabolism and regulation, damage enzymes and affect the overall cellular apparatus.

To learn more about the performance of bacterial photosynthetic RCs at various temperatures, we investigated the temperature preference of pigment synthesis, primary photochemistry, and electron transport in marine AAP bacterium Dinoroseobacter (Drb.) shibae (Biebl et al. 2005). In addition, we also used other photoheterotrophic Rhodobacterales differing in their temperature preference. The psychrotolerant bacterium Ris. antarcticus EL- $88^{\mathrm{T}}$ was isolated from Antarctic lake Ekho, the haloalkaliphile Rhodobaca (Rca.) barguzinensis alga-05 was isolated from a soda lake in Siberia (Boldareva et al. 2008), while the marine bacterium Roseobacter sp. COL2P was isolated from Mediterranean coastal waters (Koblížek et al. 2010). The function of their photosynthetic RCs at various temperatures was investigated using kinetic $\mathrm{BChl}$ fluorometry.

\section{Materials and methods}

Microbial cultures: Drb. shibae DFL-12 ${ }^{\mathrm{T}}$, Ris. antarcticus EL-88 ${ }^{\mathrm{T}}$, and Roseobacter sp. COL2P were grown in complex organics seawater media described before (Koblížek et al. 2010). Rca. barguzinensis alga-05 was grown in organic medium designed for haloalkalophic species (Boldareva et al. 2008). The aerobic cultures were incubated in $250-\mathrm{mL}$ Erlenmayer flasks with cotton plugs on an orbital shaker at specified temperatures. Illumination was provided by a bank of Dulux L 55W/865 luminescent tubes (Osram, Germany, spectral temperature of $6500 \mathrm{~K}$ ) delivering approx. $100 \mu \mathrm{mol}$ (photon) $\mathrm{m}^{-2} \mathrm{~s}^{-1}$. If not stated otherwise, the cultures were grown under 12-h dark/12-h light regime. During the experiment investigating the growth of Drb. shibae cultures at different temperatures, the late exponential phase inoculum grown in the dark at $20^{\circ} \mathrm{C}$ was diluted to $\mathrm{OD}_{600}=0.01$ with fresh growth medium and distributed into Erlenmayer flasks. The obtained subcultures were transferred into incubators with temperatures set at $8,15,20,30,35,40$, and $45^{\circ} \mathrm{C}$. The growth was followed two times per day by turbidity measurements at $600 \mathrm{~nm}$.

Fluorescence measurement: Infra-red fluorescence mea- surements were performed using a kinetic fluorometer FL-3000 (Photon Systems Instruments Ltd., Brno, Czech Republic) equipped with the 'Superhead' optical unit populated with an array of blue-green $505 \mathrm{~nm}$ Luxeon Rebel diodes. The infra-red (BChl) fluorescence signal $(\lambda>850 \mathrm{~nm})$ was detected using a silicon photodiode registering with a $10 \mathrm{MHz}$ resolution. The cells harvested at late exponential phase were diluted 10 times into fresh medium and dark adapted for half an hour at room temperature prior to probing their photosynthetic activity. Cell suspension $(2.3 \mathrm{~mL})$ was first cooled down to $10^{\circ} \mathrm{C}$ and then in the dark linearly heated to the selected temperature over a period of $10 \mathrm{~min}$. Heating period was chosen as a minimal time required for inducing a stable half inhibition of the yield of primary photochemistry of the reaction centers at $70^{\circ} \mathrm{C}$ (Fig. S1, supplement). After reaching the chosen temperature, the BChl fluorescence was elicited by a $140 \mu$ s-long square-wave pulse of light with an intensity of $\sim 0.1 \mathrm{~mol}$ (photon) $\mathrm{m}^{-2} \mathrm{~s}^{-1}$. The yield of primary photochemistry was calculated as $F_{V} / F_{M}=\left(F_{M}-F_{0}\right) / F_{M}$. Here, $\mathrm{F}_{0}$ is the minimal $\mathrm{BChl}$ fluorescence yield at time $1 \mu$ s emitted by the open reaction centers capable of charge separation. The $\mathrm{F}_{\mathrm{M}}$ is the maximal $\mathrm{BChl}$ fluorescence yield obtained after $100 \mu$ s of illumination that is emitted by the closed reaction centers that have undergone charge separation and stabilization of the electron at the quinone primary acceptor $\mathrm{Q}_{\mathrm{A}}$. The fluorescence relaxation following the maximal $\mathrm{BChl}$ fluorescence level $\mathrm{F}_{\mathrm{M}}$ was detected by 124 logarithmically spaced probing flashlets placed after the saturating pulse. The normalized BChl fluorescence decays were fitted with three exponential-decay curves by least square numerical fitting. The rate of fluorescence relaxation was expressed as a sum of three components $f(t)=a_{1} \exp \left(-k_{1} t\right)+a_{2} \exp \left(-k_{2} t\right)+a_{3} \exp \left(-k_{3} t\right)$, where $f(t)$ is the fluorescence response at time $t ; k_{1}, k_{2}$, and $k_{3}$ represent the rate constants of reoxidation of the primary quinone electron acceptor $\mathrm{Q}_{\mathrm{A}^{-}}$, and $a_{1}, a_{2}$, and $a_{3}$ their corresponding amplitude. The individual measurements were conducted over a range from 5 to $90^{\circ} \mathrm{C}$ with $2.5^{\circ} \mathrm{C}$ increments with a fresh sample for each individual measurement (i.e., in total of 35 measurements).

Other analyses and statistics: The rate of respiration was measured with Clark-type concentration electrode in a thermostated, magnetically stirred cuvette (Hansatech Instruments Ltd., UK). Electrical current at a polarization potential of $700 \mathrm{mV}$ was monitored by Oxycorder (Photon Systems Instruments Ltd., Czech Republic) with a sampling frequency of $30 \mathrm{~Hz}$. Cell suspensions of $2 \mathrm{~mL}$ were homogenously illuminated by KL2500 LED cold light source (Schott, Germany) providing white light of $200 \mu \mathrm{mol}$ (photon) $\mathrm{m}^{-2} \mathrm{~s}^{-1}$. The respiration was measured at $10,20,30,40,48$, and $55^{\circ} \mathrm{C}$. Calibration of the measured signals was carried out against a sterile growth medium equilibrated with the ambient air and then depleted of oxygen by bubbling the chamber with nitrogen. Tabulated values of oxygen concentration in saline water were used to convert measured signals into oxygen concentration $\left[\mathrm{mmol}\left(\mathrm{O}_{2}\right) \mathrm{L}^{-1}\right]$. The rate of respiration in $\operatorname{mmol}\left(\mathrm{O}_{2}\right)$ $\mathrm{g}(\mathrm{BChl} a)^{-1} \mathrm{~h}^{-1}$ was determined as a slope of linear regression 
of a plot of $\mathrm{O}_{2}$ concentration $v s$. time normalized to BChl $a$ concentration. All experiments were carried out in quadruplicates.

BChl $a$ concentration was determined using the high performance liquid chromatography (HPLC) as described before (Selyanin et al. 2016). Protein content was determined spectrophotometrically using a Lowry assay kit (Merck, Germany).

All statistical analyses were performed using SigmaPlot v. 13.0. Data are presented as mean \pm standard deviation. A value of $P<0.05$ was considered statistically significant.

\section{Results and discussion}

Temperature preference of Drb. shibae: First we investigated the temperature preference of Drb. shibae grown between 15 and $45^{\circ} \mathrm{C}$. To remove the inhibitory effect of light on pigment synthesis observed previously (Piwosz et al. 2018), we incubated all the cultures in the dark. The best growth was observed in cultures grown between 30 and $40^{\circ} \mathrm{C}$, with the maximum growth rate $\left(\sim 3.4 \mathrm{~d}^{-1}\right)$ and biomass obtained at $35^{\circ} \mathrm{C}$ (Fig. $\left.1 A\right)$. The cells incubated at $45^{\circ} \mathrm{C}$ showed only a transient increase in turbidity during the first $22 \mathrm{~h}$. On the course of the following cultivation, the turbidity showed a slow but gradual decline.

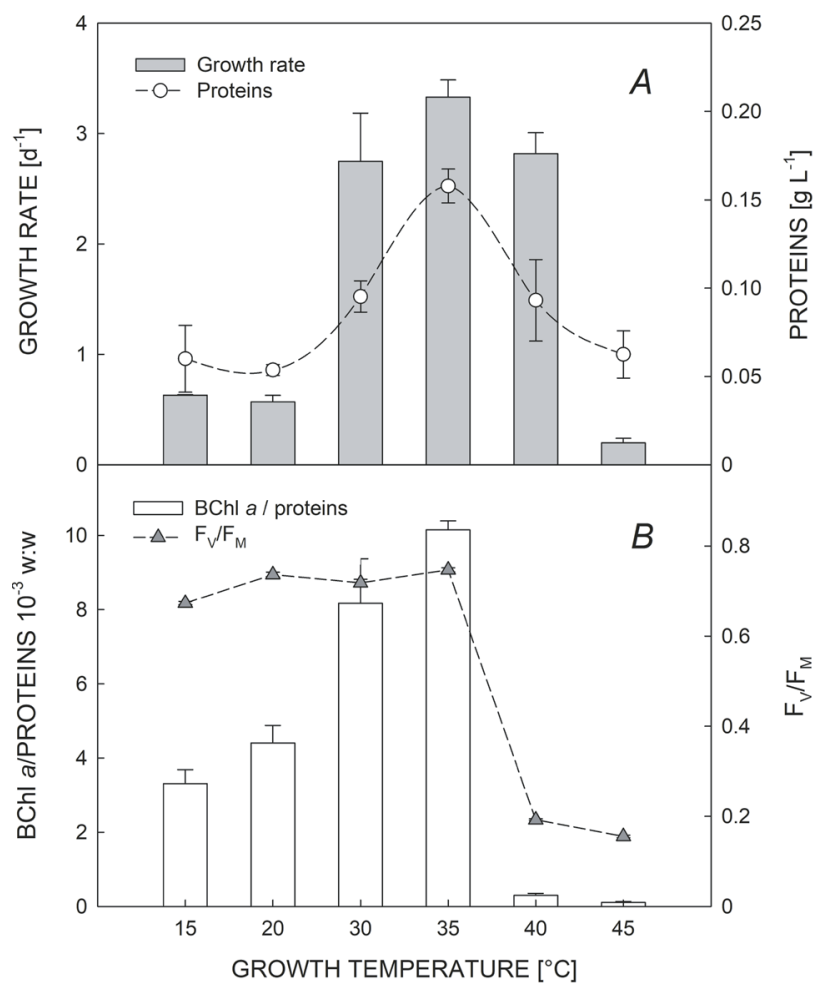

Fig. 1. Influence of cultivation temperature on Dinoroseobacter shibae grown in the dark. The initial growth rates (bars) and protein concentration reached at steady state (circles) $(A)$. BChl $a$ per protein ratio (bars) and yield of photochemistry $\mathrm{F}_{\mathrm{V}} / \mathrm{F}_{\mathrm{M}}$ (triangles) $(B)$. The error bars report the standard deviations calculated from three parallel cultures.



Fig. 2. In vivo bacteriochlorophyll fluorescence inductionrelaxation kinetics of Dinoroseobacter shibae grown at $35^{\circ} \mathrm{C}$ and briefly exposed to elevated temperatures of 10 to $80^{\circ} \mathrm{C}$. The induction of bacteriochlorophyll fluorescence from $F_{0}$ to $F_{M}$ elicited by short pulses of actinic light corresponds to a gradual closure of the photosynthetic reaction centers. The subsequent relaxation from the $\mathrm{F}_{\mathrm{M}}$ reflects the reopening of the reaction centers. The kinetics were analysed to obtain electron transfer rate constants $k_{1}, k_{2}$, and $k_{3}$.

A somewhat different picture was obtained when we looked at synthesis of photosynthetic pigments and photosynthetic RCs. Here the cultures grown at $40^{\circ} \mathrm{C}$ had significantly reduced pigmentation when compared to cultures grown at $35^{\circ} \mathrm{C}\left(310^{-4}\right.$ vs. $110^{-2} \mathrm{BChl} a$ per protein, w:w) (Fig. 1B). To further investigate this phenomenon, we tested the function of their RCs using variable $\mathrm{BChl}$ fluorometry. While the cells grown at or below $35^{\circ} \mathrm{C}$ exhibited normal high photochemical yields, $\mathrm{F}_{\mathrm{V}} / \mathrm{F}_{\mathrm{M}} \sim 0.7$, the cells grown at 40 or $45^{\circ} \mathrm{C}$ had $\mathrm{F}_{\mathrm{V}} / \mathrm{F}_{\mathrm{M}}<0.2$ (Fig. 1B). Similar phenomenon has been reported in marine AAP bacterium Erythrobacter sp. NAP1 or the slightly thermophilic bacterium Rubritepida flocculans, which may grow up to $35^{\circ} \mathrm{C}$ or at $48^{\circ} \mathrm{C}$, respectively, but they only express $\mathrm{BChl} a$ at much lower temperatures (Alarico et al. 2002, Koblížek et al. 2003).

Performance of photosynthetic reaction centers at varying temperatures: The fact that $D r b$. shibae cells can still grow well at $40^{\circ} \mathrm{C}$, but their photosynthetic apparatus is largely reduced and not functional may indicate that the photosynthetic apparatus is either unstable at higher temperatures or is not assembled at super-optimal temperatures. We therefore used the Drb. shibae culture grown at $35^{\circ} \mathrm{C}$ and tested the functionality of the RCs in vivo at various temperatures. In the set of measurements, cells were exposed to temperatures of $5-80^{\circ} \mathrm{C}$ and their photosynthetic performance was tested using variable BChl fluorescence (Fig. 2). The observed influence of elevated temperature was approximately biphasic. The recorded $\mathrm{F}_{\mathrm{V}} / \mathrm{F}_{\mathrm{M}}$ ratios remained constant up to approximately $55^{\circ} \mathrm{C}$ (Fig. 3). At higher temperatures, it gradually declined, signalizing an impaired function of the primary photochemistry. To test whether the observed 




Fig. 3. Temperature dependence of the yield of primary photochemistry $\mathrm{F}_{\mathrm{V}} / \mathrm{F}_{\mathrm{M}}$ recorded in Dinoroseobacter shibae cells grown at suboptimal, optimal, and super-optimal temperatures briefly exposed to temperatures varying between 5 to $81^{\circ} \mathrm{C}$.

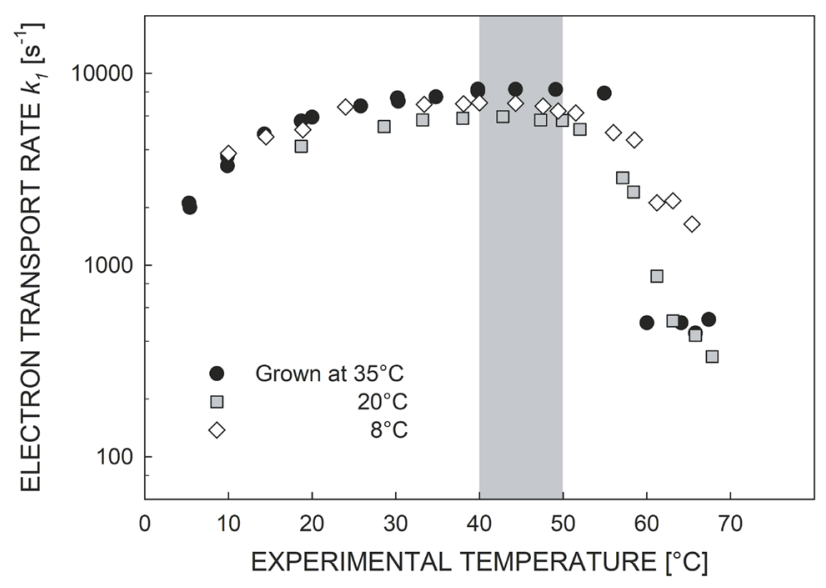

Fig. 4. Temperature dependence of electron transport rate $k_{l}$ recorded in Dinoroseobacter shibae cells grown at 8,20, and $35^{\circ} \mathrm{C}$ and briefly exposed to experimental temperatures varying between 5 to $68^{\circ} \mathrm{C}$. The grey box marks the temperature optimum.

thermal stability of the photochemical reactions depends on growth temperature, we performed a control measurement using Drb. shibae cells grown at suboptimal temperatures. The cells grown at $8^{\circ} \mathrm{C}$ retained constant $\mathrm{F}_{\mathrm{V}} / \mathrm{F}_{\mathrm{M}}$ ratios $(\sim 0.66)$ up to $58^{\circ} \mathrm{C}$ and declined only at experimental temperatures above $60^{\circ} \mathrm{C}$ (Fig. 3).

Photosynthetic reactions catalysed by the reaction centers that follow the primary charge separation and stabilization involve the forward transport of the separated charges from the primary electron acceptor $\mathrm{Q}_{\mathrm{A}}$ to the secondary acceptor $\mathrm{Q}_{\mathrm{B}}$. We used the relaxation part of the variable fluorescence measurements (Fig. 2) to deconvolute the $\mathrm{Q}_{\mathrm{A}}^{-}$reoxidation rate constants for $D r b$. shibae cells grown at $35^{\circ} \mathrm{C}$. Interestingly, the determined electron transport rate constant $k_{l}$ had a broad temperature optimum between 25 to $50^{\circ} \mathrm{C}$, reaching its maximum rate $\left(8,263 \mathrm{~s}^{-1}\right)$ at $44^{\circ} \mathrm{C}$ (Fig. 4). At temperatures above $55^{\circ} \mathrm{C}$, the electron transport rapidly declined.

Since we wanted to learn whether the extended electron transport optimum is an internal characteristic of the reaction centers or it is affected by the fluidity of the photosynthetic membranes, we conducted the measurements of electron transport rates in cultures grown at 8 and $25^{\circ} \mathrm{C}$, which is significantly lower than optimum temperature. We saw the same temperature dependencies of electron transport rates as in the culture grown at $35^{\circ} \mathrm{C}$ (Fig. 4). There was only a small shift of the $k_{1}$ maximum which was found at 40 and $43^{\circ} \mathrm{C}$ for cultures grown at 8 and $20^{\circ} \mathrm{C}$, respectively. These measurements indicate that the observed high temperature optima originate from the inherent characteristics of the RCs and they are not significantly modulated by the thermal adaptation of the individual cultures.

Thermal stability of phototrophic Rhodobacterales: To test whether the observed extended temperature stability is a more universal phenomenon, we decided to perform several similar experiments on closely related phototrophic species. Two Rhodobacterales species (Rca. barguzinensis and Roseobacter sp. COL2P) were mesophilic, Antarctic bacterium Ris. antarcticus was psychrotolerant (Table 1). In spite of the differing temperature preferences, the recorded $\mathrm{F}_{\mathrm{V}} / \mathrm{F}_{\mathrm{M}}$ ratios remained high well above $50^{\circ} \mathrm{C}$ for all studied Rhodobacterales strains (not shown). The same trend was observed for the electron transfer. The examined species maintained high electron transfer rates above $40^{\circ} \mathrm{C}$. The electron transfer then typically declined above $50^{\circ} \mathrm{C}$ (Fig. 5). Moreover, the psychrophilic bacterium Ris. antarcticus showed its electron transfer maximum at $48^{\circ} \mathrm{C}\left(k_{1}=5,482 \mathrm{~s}^{-1}\right.$; Fig. 5), which was $30^{\circ} \mathrm{C}$ above its growth temperature. All these results demonstrate that the photosynthetic reaction centers in all investigated Rhodobacterales share the same temperature optima, which are not related to the growth optimum of the particular strain. Similar trends were observed also in Alphaproteobacterium Erythrobacter sp. NAP1 (Fig. S2, supplement), which documents that the extended temperature optimum is not restricted only to phototrophic Rhodobacterales.

Analogy of mitochondrial membranes: It is very interesting to note that the observed temperature maxima of the rapid electron transfer between 40 and $50^{\circ} \mathrm{C}$ corresponds well with the optimum temperature reported recently for key enzymes involved in oxidative phosphorylation in mitochondria (Chrétien et al. 2018). It was found that mitochondrial cytochrome $c$ oxidases had temperature optima around $50^{\circ} \mathrm{C}$, while ATPase optimum was around $46^{\circ} \mathrm{C}$ (Chrétien et al. 2018). The higher temperature optimum in mitochondria was put in context with the fact that highly metabolically active mitochondria elevate their internal temperature by up to $10^{\circ} \mathrm{C}$ above the ambient.

A similar situation may actually also occur in photosynthetic membranes, which may internally overheat due to the fact that a large part of the absorbed light energy 
Table 1. Optimum growth temperatures, the cultivation temperature, and the temperature of the maximal electron transport rate $k_{l}\left(T_{\mathrm{MAX}}\right)$ of the investigated organisms. Optimum growth temperatures were taken from the literature (Labrenz et al. 2005, Boldareva et al. 2008, Koblížek et al. 2010).

\begin{tabular}{llcc}
\hline Species & Optimum growth temperature $\left[{ }^{\circ} \mathrm{C}\right]$ & Cultivation temperature $\left[{ }^{\circ} \mathrm{C}\right]$ & $T_{\mathrm{MAx}}\left[{ }^{\circ} \mathrm{C}\right]$ \\
\hline Dinoroseobacter shibae DFL-12 & $25-37$ & 8 & 40 \\
& & 20 & 43 \\
& & 35 & 44 \\
Rhodobaca barguzinensis alga-05 & $20-35$ & 25 & 45 \\
Roseisalinus antarcticus EL-88 & $16-26$ & 18 & 48 \\
Roseobacter sp. COL2P & $20-33$ & 23 & 47 \\
\hline
\end{tabular}

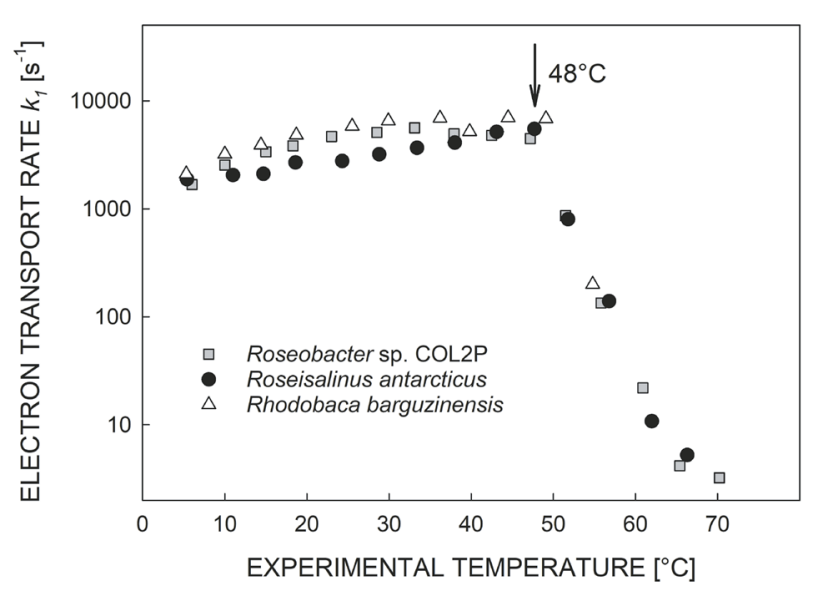

Fig. 5. Temperature dependence of electron transfer rate $k_{l}$ recorded in marine bacterium Roseobacter sp. COL2P grown at $23^{\circ} \mathrm{C}$, psychrotolerant bacterium Roseisalinus antarcticus grown at $18^{\circ} \mathrm{C}$, and haloalkaliphilic bacterium Rhodobaca barguzinensis grown at $25^{\circ} \mathrm{C}$.



Fig. 6. Temperature dependence of respiration of Dinoroseobacter shibae grown at $35^{\circ} \mathrm{C}$. The rate of $\mathrm{O}_{2}$ respiration was measured in the dark and under illumination of $200 \mu \mathrm{mol}$ (photon) $\mathrm{m}^{-2} \mathrm{~s}^{-1}$.

is dissipated as heat. Therefore it is important that the $\mathrm{RC}$ centers can operate even at higher than ambient temperatures. Also, it is important to note that mitochondria evolved from Alphaproteobacteria which entered the eukaryotic host (Gray 2012). So, mitochondria and Alphaproteobacteria share many common characteristics, such as membrane organization and composition. We may speculate that they also inherited the same temperature preference.

To test this hypothesis, we investigated the thermal stability of enzymes involved in the oxidative phosphorylation by measuring the rate of $\mathrm{O}_{2}$ respiration in the dark and also under illumination of $200 \mu \mathrm{mol}$ (photon) $\mathrm{m}^{-2} \mathrm{~s}^{-1}$. Fig. 6 shows the respiration activity in Drb. shibae rose from $20-40^{\circ} \mathrm{C}$ with an optimum between $40-48^{\circ} \mathrm{C}$ that was followed by a steep decline. The photophosphorylation activity reflected in the difference between dark and light respiration (Koblížek et al. 2010) has also the maximum extent at $48^{\circ} \mathrm{C}$. This confirms that also enzymes involved in respiration exhibit extended temperature stability in the same range as photosynthetic electron transport. These findings also positively support the temperature optima documented for ATPase and cytochrome $c$ oxidases by Chrétien et al. (2018).

Heat production model: We are not aware of any study which would determine the internal temperature of the active photosynthetic membranes and this topic certainly deserves closer attention. Therefore, we attempted to estimate the heat produced by illuminated photosynthetic membranes inside of a thermally isolated cell of Drb. shibae. The single cell contains $c a$. 3,000 reaction centers (Piwosz et al. 2018) that represent moderately pigmented cells when compared with the values of $\sim 150-30,000$ $\mathrm{RC}$ per cell found in a representative sample of purple nonsulfur and AAP bacteria by Selyanin et al. (2016). The investigated species living in the aquatic environments where they are exposed mostly to the blue-green light spectrum (infra-red part of the spectrum is rapidly removed in the water column). Approximately half of the energy of a blue photon $(\lambda=440 \mathrm{~nm})$, which has been absorbed by a reaction center $(\sim 870 \mathrm{~nm})$, is dissipated as heat $(E=1.4$

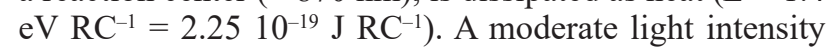
of $400 \mu \mathrm{mol}$ (photon) $\mathrm{m}^{-2} \mathrm{~s}^{-1}$ of blue light will cause an effective flux of approx. 100 hits per reaction center per second. Each RC will dissipate heat of 22.5 aJ per second. Collectively, all reaction centers in the cell produce a heat of $67.5 \mathrm{fJ} \mathrm{s}^{-1}$. With a volume of the cell being estimated to $0.5 \mu \mathrm{m}^{3}$ it contains an approximated $0.5 \mathrm{fL}$ of water 
weighting $0.5 \mathrm{pg}$. Assuming that the heat capacity of the cell is mostly dictated by water $\left(C_{\mathrm{H} 2 \mathrm{O}}=4.2 \mathrm{~J} \mathrm{~K}^{-1} \mathrm{~g}^{-1}\right)$, we estimate the photosynthetic membranes illuminated with blue light will receive thermal energy corresponding to $0.032 \mathrm{~K} \mathrm{~s}^{-1}$ or $1.92 \mathrm{~K} \mathrm{~min}^{-1}$. This is somewhat lower than the estimated heat production of $4.58 \mathrm{~K} \mathrm{~min}^{-1}$ in mitochondria by Chrétien et al. (2018), but in more pigmented cells or under more intense irradiance the produced heat may increase several fold. The assumption of the thermally isolated cell is, obviously, a theoretical construct. In the real world, the heat is (after the temperature gradient builds up) transferred to the surrounding water. Still, our calculation provides an information of the extent of the heat production in the photosynthetic membranes.

Conclusions: The main observation of this study is that the electron transport optimum of the photosynthetic reaction centers in Rhodobacterales is extended to significantly higher temperatures than that of their growth optima. This phenomenon was observed in all the studied species irrespective of the cultivation temperature. This suggests that it is an intrinsic characteristic of photosynthetic RCs. Similarly, an extended temperature optimum was also found in enzymatic system responsible for oxidative phosphorylation. We speculate that the extended temperature optimum of the photosynthetic reactions may have evolved to cope with the risk of internal overheating due to heat released from light absorbed during photosynthesis.

\section{References}

Alarico S., Rainey F.A., Empadinhas N. et al.: Rubritepida flocculans gen. nov., sp. nov., a new slightly thermophilic member of the alpha-1 subclass of the Proteobacteria. - Syst. Appl. Microbiol. 25: 198-206, 2002.

Biebl H., Allgaier M., Tindall B.J. et al.: Dinoroseobacter shibae gen. nov., sp. nov., a new aerobic phototrophic bacterium isolated from dinoflagellates. - Int. J. Syst. Evol. Micr. 55: 1089-1096, 2005.

Boldareva E.N., Akimov V.N., Boychenko V.A. et al.: Rhodobaca barguzinensis sp. nov., a new alkaliphilic purple nonsulfur bacterium isolated from a soda lake of the Barguzin Valley (Buryat Republic, Eastern Siberia). - Microbiology 77: 206218, 2008 .

Brinkhoff T., Giebel H.A., Simon M.: Diversity, ecology, and genomics of the Roseobacter clade: a short overview. - Arch. Microbiol. 189: 531-539, 2008.

Chrétien D., Bénit P., Ha H.-H. et al:: Mitochondria are physiologically maintained at close to $50^{\circ} \mathrm{C}$. - PLoS Biol. 16: doi: 10.1371/journal.pbio.2003992, 2018.

Ferrera I., Borrego C.M., Salazar G., Gasol J.M.: Marked seasonality of aerobic anoxygenic phototrophic bacteria in the coastal NW Mediterranean Sea as revealed by cell abundance, pigment concentration and pyrosequencing of puf $M$ gene. -
Environ. Microbiol. 16: 2953-2965, 2014.

Gray M.W.: Mitochondrial evolution. - CSH Perspect. Biol. 4: doi: 10.1101/cshperspect.a011403, 2012.

Kalashnikov A.M., Gaisin V.A., Sukhacheva M.V. et al.: Anoxygenic phototrophic bacteria from microbial communities of Goryachinsk thermal spring (Baikal Area, Russia). - Microbiology 83: 407-421, 2014.

Kimura Y., Yu L.J., Hirano Y. et al.: Calcium ions are required for the enhanced thermal stability of the light-harvestingreaction center core complex from thermophilic purple sulfur bacterium Thermochromatium tepidum. - J. Biol. Chem. 284: 93-99, 2009.

Kobližzek M.: Ecology of aerobic anoxygenic phototrophs in aquatic environments. - FEMS Microbiol. Rev. 39: 854-870, 2015.

Koblížek M., Béjà O., Bidigare R.R. et al.: Isolation and characterization of Erythrobacter sp. strains from the upper ocean. - Arch. Microbiol. 180: 327-338, 2003.

Koblížek M., Mlčoušková J., Kolber Z., Kopecký J.: On the photosynthetic properties of marine bacterium COL2P belonging to Roseobacter clade. - Arch. Microbiol. 192: 4149, 2010.

Koblížek M., Zeng Y., Horák A., Oborník M.: Regressive evolution of photosynthesis in the Roseobacter clade. - Adv. Bot. Res. 66: 385-405, 2013.

Labrenz M., Collins M.D., Lawson P.A. et al.: Roseovarius tolerans gen. nov., sp. nov., a budding bacterium with variable bacteriochlorophyll $a$ production from hypersaline Ekho Lake. - Int. J. Syst. Bacteriol. 49: 137-147, 1999.

Labrenz M., Lawson P.A., Tindal B.J. et al.: Roseisalinus antarcticus gen. nov., sp. nov., a novel aerobic bacteriochlorophyll $a$-producing alpha-proteobacterium isolated from hypersaline Ekho Lake, Antarctica. - Int. J. Syst. Evol. Micr. 55: 41-47, 2005.

Labrenz M., Tindall B.J., Lawson P.A. et al.: Staleya guttiformis gen. nov., sp. nov. and Sulfitobacter brevis sp. nov., alpha-3Proteobacteria from hypersaline, heliothermal and meromictic antarctic Ekho Lake. - Int. J. Syst. Evol. Micr. 50: 303-313, 2000.

Madigan M.T., Jung D.O. An overview of purple bacteria: systematics, physiology, and habitats. - In: Hunter C.N., Daldal F., Thurnauer M.C., Beatty J.T. (ed.): The Purple Phototrophic Bacteria. Pp. 1-15. Springer Science, New York 2009.

Mašín M., Zdun A., Stoń-Egiert J. et al:: Seasonal changes and diversity of aerobic anoxygenic phototrophs in the Baltic Sea. - Aquat. Microb. Ecol. 45: 247-254, 2006.

Nozawa T., Madigan M.T.: Temperature and solvent effects on reaction centers from Chloroflexus aurantiacus and Chromatium tepidum. - J. Biochem.-Tokyo 110: 588-594, 1991.

Piwosz K., Kaftan D., Dean J. et al.: Nonlinear effect of irradiance on photoheterotrophic activity and growth of the aerobic anoxygenic phototrophic bacterium Dinoroseobacter shibae. - Environ. Microbiol. 20: 724-733, 2018.

Selyanin V., Hauruseu D., Koblížek M.: The variability of lightharvesting complexes in aerobic anoxygenic phototrophs. Photosynth. Res. 128: 35-43, 2016.

(C) The authors. This is an open access article distributed under the terms of the Creative Commons BY-NC-ND Licence. 